Annals of Warsaw University of Life Sciences - SGGW

Land Reclamation No 40, 2008: 67-76

(Ann. Warsaw Univ. of Life Sci. - SGGW, Land Reclam. 40, 2008)

\title{
Appraisal of suspended sediment concentration on reference level according to van Rijn's method
}

\author{
BOGUSŁAW MICHALEC
}

Department of Water Engineering, Agriculture University in Cracow

\begin{abstract}
Appraisal of suspended sediment concentration on reference level according to van Rijn's method. The paper presents the results of sediment concentration measurements in the River Dłubnia at differentiated discharges of $0.44 \mathrm{~m}^{-3} \cdot \mathrm{s}^{-1}$, $1.96 \mathrm{~m}^{-3} \cdot \mathrm{s}^{-1}$ and $7.41 \mathrm{~m}^{-3} \cdot \mathrm{s}^{-1}$. The elaborated concentration profiles based on hydrometric measurements permitted determination of $\mathrm{Ca}$ concentration on reference level "a" above the bed. The obtained reference concentrations were compared with the values obtained from calculations by use of van Rijn's formula. It was found that the calculated $\mathrm{Ca}$ concentration, applying the van Rijn's formula, is over five times higher than determined from concentration profiles. In order to obtain $\mathrm{Ca}$ concentration values, calculated by use of the empiric formula, approximate to real values coefficient correction must be determined. The elaborated preliminary estimation of the possibility of van Rijn's formula application for determination of this concentration on the reference level "a" above the bed showed that application of this method for appraisal of $\mathrm{Ca}$ concentration, by use van Rijn's formula, performed in the Dhubnia river of the catchment of the Upper Vistula river may be charged by errors. A faulty calculation of suspension sediment transport applying van Rijn's method may also point to it. Adoption of this method needs further verification and adaptation.
\end{abstract}

Key words: river, suspended sediment, sediment concentration, concentration profile.

\section{INTRODUCTION}

Intensity of suspended sediment transport may be determined by use of various methods i.e. direct ones - measurement methods and indirect - calculation ones. Among the direct ones the following ones may be distinguished: bathometric, photometric, electro-resistance, ultrasonic and radioisotope method. Indirect methods permit to calculate sediment transport basing upon empiric, semi-empiric and theoretical equations. Calculation methods that serve to establish the quantity of suspended sediment transport are based upon determination of parameters describing water and sediment discharges in the river or series of factors influencing erosion in the basin and the amount of material supplied to the river. These are mostly empirical methods. Among the most frequently applied indirect methods of appraisal of suspended sediment transport used in Poland those basing upon a determined mass of eroded soil in the basin may be mentioned. From those the most commonly applied is, up till now, the Reniger-Dębski's method (Wiśniewski, Kutrowski 1973) based on classification of denudation intensity and the method of run off denudation indices used by Brański (1975) and the DR-USLE method based upon the universal soil loss equation USLE (Wischmeier, Smith 1965) in which the index of sediment discharge is determined by use of the method given by Roehl (1962). Among the calculation methods based on 
appraisal of parameters describing water and sediment discharge in river the van Rijn's method (1984) is more and more frequently applied. Mokwa's (2002) and Bartnik's et al. (2004) publications presenting the results of application of this method for South Poland rivers are, among others, a good example. Possibility of applications of van Rijn's method in calculations of suspended sediment transport in Carpathian rivers has not been, as yet, verified. This method was elaborated in result of investigation in the hydraulic laboratory in Delft and verified by van Rijn (1984) for data obtained from measurements in estuary sections of Dutch rivers (Eastern Schheldt). This method is based on the assumption that particles remain in state of rest when the value of overall bed-shear velocity $\left(\mathrm{u}_{*}\right)$ is lower than the critical bed-shear velocity for initiation of motion $(\mathrm{u} * \mathrm{cr})$. When the overall bed-shear velocity exceeds the critical bed-shear velocity for initiation of motion, movement of particles begins (rolling, sliding motion) in permanent contact with the bed. With increase of overall bed-shear velocity particles may be further displaced on the bed or perform more or less regular jumps, with are called saltations. The increasing overall bed-shear velocity exceeding the particle fall velocity causes their permanent suspension. In this way individual particles are further transported as suspended sediment. Analysing the two-phase medium van Rijn introduced into his analysis two parameters characterizing the movement of sediment i.e. transport stage parameter (T) and the particle diameter $\left(\mathrm{D}_{*}\right)$ as:
$\mathrm{T}=\frac{\left(\mathrm{u}_{*}\right)^{2}-\left(\mathrm{u}_{* \mathrm{cr}}\right)^{2}}{\left(\mathrm{u}_{\mathrm{cr}}\right)^{2}}$

where:

$u^{\prime} *$ - bed-shear velocity related to grains $\left[\mathrm{m} \cdot \mathrm{s}^{-1}\right]$,

$\mathrm{u} *_{\mathrm{cr}}$ - critical bed-shear velocity for initiation of motion (according to Shields) $\left[\mathrm{m} \cdot \mathrm{s}^{-1}\right]$.

$$
D_{*}=d_{50}\left[\frac{\left(\rho_{\mathrm{s}}-\rho\right) \cdot g}{v^{2}}\right]^{1 / 3}
$$

where:

$v$ - kinematic viscosity coefficient $\left[\mathrm{m} \cdot \mathrm{s}^{-1}\right]$,

$\mathrm{g}-$ acceleration of gravity $\left[\mathrm{m} \cdot \mathrm{s}^{-2}\right]$,

$\rho_{\mathrm{s}}-$ specific density of sediment $\left[\mathrm{kg} \cdot \mathrm{m}^{-3}\right]$,

$\rho-$ specific density of water $\left[\mathrm{kg} \cdot \mathrm{m}^{-3}\right]$,

$\mathrm{d}_{50}$ - particle diameter of sediment [m].

Basing upon equations of concentration distribution in the vertical according to Rouse, with assumption of logarithmic distribution of flow velocity van Rijn proposes to write the equation of concentration in the vertical in the following form:

$\frac{C}{C_{a}}=\left[\frac{a}{h-a}\right]^{z} \exp \left[-4 Z\left(\frac{z}{h}-0.5\right)\right]$

for $\frac{\mathrm{z}}{\mathrm{h}} \geq 0.5$

where:

$\mathrm{C}$ - sediment concentration $\left[\mathrm{g} \cdot \mathrm{m}^{-3}\right]$,

$\mathrm{C}_{\mathrm{a}}$ - reference concentration (concentration on reference level "a" above bed) $\left[\mathrm{g} \cdot \mathrm{m}^{-3}\right]$, $\mathrm{a}$ - height of reference level [m], 
$\mathrm{z}$ - vertical coordinate $[\mathrm{m}]$,

$\mathrm{h}-$ depth of water [m],

$\mathrm{Z}$ - suspension parameter [-], expressed by:

$$
\mathrm{Z}=\frac{\omega}{\beta \cdot \kappa \cdot \mathrm{u}_{*}}
$$

where $\omega$ is the settling velocity of suspended sediment, $\beta$ - diffusion coefficient and $\kappa$ is constant von Karman.

The height of reference level "a" above the bed is adopted as a half of the height of bed-forms or equal to the equivalent roughness $\mathrm{k}_{\mathrm{s}}$ according to Nikuradse. It the height of bed-forms is unknown the minimal value of the reference level $a_{\min }$ equal $0.01 \mathrm{~h}$ is adopted. In the formula elaborated by van Rijn used for calculation of sediment transport appraisal of $\mathrm{C}_{\mathrm{a}}$ concentration on the reference level "a" above bed is necessary. The reference concentration is defined by van Rijn's formula:

$$
\mathrm{C}_{\mathrm{a}}=\frac{0.035}{ \pm_{2}} \cdot \frac{\mathrm{d}_{50}}{\mathrm{a}} \cdot \frac{\mathrm{T}^{1.5}}{\mathrm{D}_{*}^{0.3}}
$$

The concentration coefficient $\alpha_{2}$, equal 2,3, was established by van Rijn's basis on laboratory and in situ research results. Since there is no verification of this equation in conditions of rivers of South Poland the obtained calculation results may depart from the values of real concentration $\mathrm{C}_{\mathrm{a}}$ of the sediment and of the intensity of suspended sediment transport. Determination of suspended sediment concentration $\mathrm{C}_{\mathrm{a}}$ from concentration profiles elaborated on the basis of the results of measurements in situ and their comparison with calculation results according to formula (5) elaborated by van Rijn' may constitute the basis of appraisal of application possibilities of this formula. This paper aims at carrying out a verification of possibilities of determination of suspended sediment concentration $\mathrm{C}_{\mathrm{a}}$ according to van Rijn's formula. The verification was performed on the basis of the data obtained from researches in situ carried out in the River Dłubnia.

\section{MATERIALS AND METHODS}

The River Dłubnia of total length $53.2 \mathrm{~km}$ is a left bank tributary of the Vistula river. The catchment area equals $274 \mathrm{~km}^{2}$. The springs of the Dhubnia river are located on the Cracow Upland and the river flows across the Miechów Upland, Proszowice Upland and find the estuary in the Vistula river valley at the $89+400 \mathrm{~km}$ of the Vistula river course.

Surface of the catchment is built of surface formation, very strongly eroded forming a layers of loess $15 \mathrm{~m}$ deep. The loess layers covering the valleys were partly or totally washed away from the ridges of elevations. As a rule loess is permeable and it is characterized by big water capacity (Dynowska, Tlałka 1970). A rather poor forest overgrowth of the catchment covering only $9.5 \%$ is not conducive to effective water retention in the catchment. Most part of the catchment is under arable land. These constitute $78.1 \%$ of the catchment area, green areas cover $1.6 \%$, and the other territories constitute $10.8 \%$ (Bednarczyk 1994). In consequence of the dominating agricultural utilization and system of development of the catchment, where 
arable land adjoins simply the flows great amounts of fine grained mineral material is carried away from the catchment. This has a very negative influence on water conditions in this territory, it accelerates the surface run off, hence, erosion of soil. During more intensive rains the ploughed furrows play the role of small channels along which rain water easily flows down. Especially intensive flow off of this kind takes place in periods when these is no floral cover in spring and autumn. Specificity of development of the catchment and structure of its surface formations is a cause of intensive suspended sediment transport in the Dłubnia river.

Measurements of suspended sediment concentration were made in cross-section A-A at the $10+720 \mathrm{~km}$ of the Dłubnia river (Fig. 1). This section is beyond the reach of the back water of the reservoir at Zesławice. The place for the test section was adopted in consequence of the previously performed stock taking along the river sector from the inflow into the reservoir $(9+300 \mathrm{~km})$ to the section at $10+900 \mathrm{~km}$ located below the weir at
Raciborowice. The A-A cross-section was founded during the first bathometric measurements carried out in 1999.

Simultaneously with measurements of the suspended sediment concentration measurements of water flow velocity were taken. The measurements were performed at different heights of the appointed hydrometric verticals. Suspended sediment concentration was determined byuse of a photooptical device Portable Suspended Solids and Turbidity Monitor System 770 Partech made. The water flow velocity was measured by use of a current meter of Nautilus C 2000 OTT Hydrometrie type. Measurements of flow velocity were performed in seven hydrometric verticals assuming the minimal number of measurement level in each of the verticals according to the method given in the PIHM instruction and "Measurement Procedure" IMGW (2002) i.e. at the height $0.2,0.4$ and 0.8 of the given vertical. During investigations measurements were also taken at various additional heights. Proper appraisal of application possibility of van Rijn's formula for determination

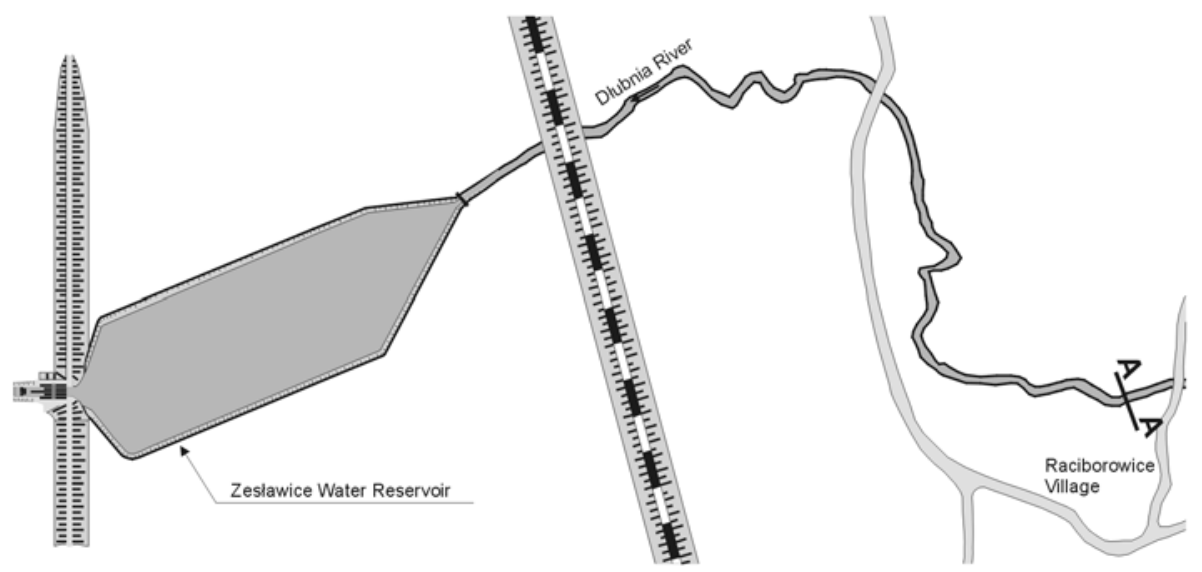

FIGURE 1. The location of measuring cross-section A-A 
of $\mathrm{C}_{\mathrm{a}}$ concentration requires additional measurements and calculations for differentiated discharges both low and medium as well as high ones. Out of technical reasons, unabling performance of measurements of significantly high discharges, characterized by high flow velocities and depth in the Dhubnia river, measurements were carried out at low and medium depth. The medium low discharges (SNQ) in the water gauge station at Zesławice is $0.44 \mathrm{~m}^{3} \cdot \mathrm{s}^{-1}$, and annual mean discharge (SSQ) equals $1.25 \mathrm{~m}^{3} \cdot \mathrm{s}^{-1}$. Measurements were taken in the spring and summer period 2006 at discharges equal $0.44 \mathrm{~m}^{3} \cdot \mathrm{s}^{-1}, 1.96$ $\mathrm{m}^{3} \cdot \mathrm{s}^{-1}$ and $7.41 \mathrm{~m}^{3} \cdot \mathrm{s}^{-1}$ respectively. In order to appraise the granulometric composition of the sediment in the cross-section A-A in the Dhubnia river the sediment was sampled from the river bed. Granulometric composition was determined by use of the Cassagrende's method in Pruszyński's modification (PN-R-04032 1998). Volumetric density of the sampled sediment was also appraised. of the Dłubnia river for the examined discharges and average concentration are given in Table 1.

On the basis of measurements results of suspended sediment concentration profiles were elaborated for each vertical. Exemplary concentration profiles appraised at discharge equaling $7.41 \mathrm{~m}^{3} \cdot \mathrm{s}^{-1}$ are given in Figure 2 . Concentration profiles were described by means of exponential equations according to the method presented in van Rijn's (1984) paper. Numeration of verticals was adopted starting from the left to the right bank of the Dlubnia river.

Calculating sediment concentration on the reference level appraisal of the bed form height is essential. It was found that at the examined discharges no bed forms occurred in the Dhubnia river. According to van Rijn's method (1984) the reference level "a" equaling 0.01 of the depth at the particular measurement vertical was adopted. Concentration of the sediment was calculated on the reference level "a" according to formula (5) in which

TABLE 1. Results of measurements in Dłubnia river in cross-section A-A

\begin{tabular}{|l|c|c|c|}
\hline $\begin{array}{l}\text { Maximal depth } \\
\mathrm{h}_{\max }[\mathrm{m}]\end{array}$ & $\begin{array}{c}\text { Discharge } \\
\mathrm{Q}\left[\mathrm{m}^{3} \cdot \mathrm{s}^{-1}\right]\end{array}$ & $\begin{array}{c}\text { Average flow } \\
\text { velocity } \\
\mathrm{V}_{\mathrm{S}}\left[\mathrm{m} \cdot \mathrm{s}^{-1}\right]\end{array}$ & $\begin{array}{c}\text { Average sediment concentration } \\
\text { in cross-section } \\
\mathrm{P}\left[\mathrm{g} \cdot \mathrm{m}^{-3}\right]\end{array}$ \\
\hline 0.42 & 0.44 & 0.45 & 24.50 \\
\hline 0.77 & 1.96 & 0.69 & 168.80 \\
\hline 1.50 & 7.41 & 0.99 & 202.90 \\
\hline
\end{tabular}

\section{RESULTS AND DISCUSSION}

The appraised diameter $\mathrm{d}_{50}$ of the sediment building the bed of the Dlubnia river in section A-A is $0.4 \mathrm{~mm}$. Specific density of sediments is $2.61 \mathrm{t} \cdot \mathrm{m}^{-3}$. Maximal depth the correction coefficient $\alpha_{2}$ is equal 2.3 according to van Rijn's establishments. Detailed calculation results of parameters of equations (2), (3) and (5) for discharges $7.41 \mathrm{~m}^{3} \cdot \mathrm{s}^{-1}$ are given in Table 2 . In this table values of calculated reference sediment concentrations appraised 


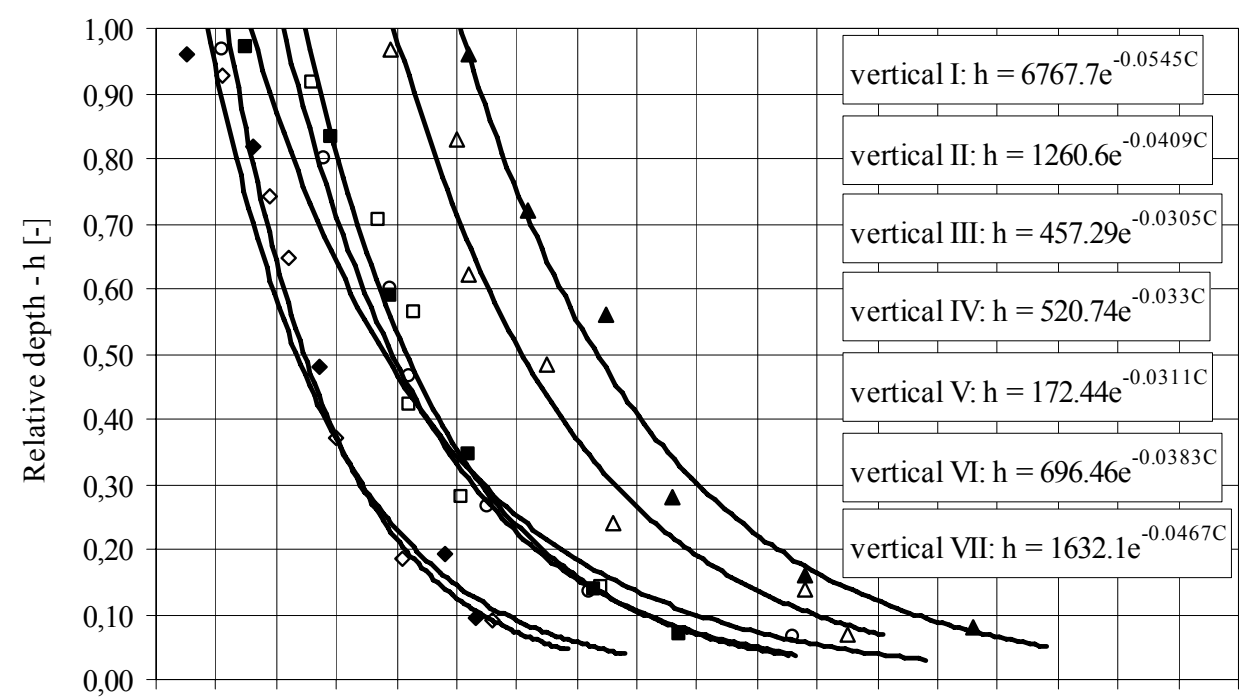

$\begin{array}{lllllllllllllllllll}150 & 160 & 170 & 180 & 190 & 200 & 210 & 220 & 230 & 240 & 250 & 260 & 270 & 280 & 290 & 300 & 310 & 320 & 330\end{array}$ Suspended sediment concentration $-\mathrm{C}\left[\mathrm{g} \cdot \mathrm{m}^{3}\right]$

$\diamond$ vertical I $\square$ vertical II $\Delta$ vertical III $\Delta$ vertical IV o vertical V $\bullet$ vertical VI • vertical VII

FIGURE 2. The concentration profile of suspended sediment for discharge $7.41 \mathrm{~m}^{3} \cdot \mathrm{s}^{-1}$

TABLE 2. Characteristics of suspended sediment transport in the Dłubnia river in cross-section A-A for discharge $7.41 \mathrm{~m}^{-3} \cdot \mathrm{s}^{-1}$

\begin{tabular}{|l|c|c|c|c|c|c|c|}
\hline \multirow{2}{*}{ Parameter } & \multicolumn{7}{|c|}{ Measurement verticals } \\
\cline { 2 - 8 } & I & II & III & IV & V & VI & VII \\
\hline $\begin{array}{l}\text { Distance from the left bank } \\
-\mathrm{L}[\mathrm{m}]\end{array}$ & 1.10 & 1.90 & 2.70 & 3.50 & 4.35 & 5.15 & 6.25 \\
\hline Vertical depth $-\mathrm{h}[\mathrm{m}]$ & 0.54 & 0.71 & 1.25 & 1.45 & 1.50 & 1.44 & 1.04 \\
\hline $\begin{array}{l}\text { Mean flow velocity in vertical } \\
-\overline{\mathrm{u}}\left[\mathrm{m} \cdot \mathrm{s}^{-1}\right]\end{array}$ & 0.692 & 0.803 & 1.049 & 1.102 & 1.099 & 1.056 & 0.892 \\
\hline $\begin{array}{l}\text { Overall bed-shear velocity - } \\
\mathrm{u} *\left[\mathrm{~m} \cdot \mathrm{s}^{-1}\right]\end{array}$ & 0.086 & 0.099 & 0.131 & 0.141 & 0.144 & 0.141 & 0.120 \\
\hline $\begin{array}{l}\text { Bed-shear velocity related to } \\
\text { grains }-\mathrm{u} *\left[\mathrm{~m} \cdot \mathrm{s}^{-1}\right]\end{array}$ & 0.031 & 0.035 & 0.043 & 0.045 & 0.045 & 0.043 & 0.038 \\
\hline $\begin{array}{l}\text { Stage transport parameter }-\mathrm{T} \\
{[-]}\end{array}$ & 5.292 & 6.959 & 11.047 & 11.895 & 11.753 & 10.857 & 8.063 \\
\hline Particle diameter $-\mathrm{D} *[-]$ & 0.82 & 0.82 & 0.82 & 0.82 & 0.82 & 0.82 & 0.82 \\
\hline $\begin{array}{l}\text { Reference sediment } \\
\text { concentration according to } \\
\text { measurements }-\mathrm{C}_{\mathrm{a}}\left[\mathrm{g} \cdot \mathrm{m}^{-3}\right]\end{array}$ & 229.8 & 254.3 & 302.2 & 301.0 & 278.0 & 256.0 & 225.5 \\
\hline $\begin{array}{l}\text { Reference sediment } \\
\text { concentration according } \\
\text { to equation }(5)\left(\alpha_{2}=2.3\right) \\
-\mathrm{C}_{\mathrm{a}}\left[\mathrm{g} \cdot \mathrm{m}^{-3} \text { ] }\right.\end{array}$ & 1220.2 & 1399.4 & 1589.8 & 1531.3 & 1453.9 & 1344.6 & 1191.5 \\
\hline
\end{tabular}


according to van Rijn's equation (5) and determined from concentration profiles were comparison.

Reference concentration calculated according to van Rijn's formula in each of the verticals at discharge of $7.41 \mathrm{~m}^{3}$. $\cdot \mathrm{s}^{-1}$ is on the average over 5.2 times higher than the one obtained from concentration profiles. In result of calculations of reference concentration in measurement verticals at discharges 0.44 $\mathrm{m}^{-3} \cdot \mathrm{s}^{-1}, 1.96 \mathrm{~m}^{-3} \cdot \mathrm{s}^{-1}$ and $7.41 \mathrm{~m}^{-3} \cdot \mathrm{s}^{-1}$ it was found that $\mathrm{C}_{\mathrm{a}}$ concentration calculated according to van Rijn's formula is on the 4.8 times higher that obtained from concentration profiles. Disposing of measurements of concentration and of elaborated concentration profiles an attempt was undertaken at establishing the correction coefficient $\alpha_{2}$. It was determined from the transformed equation (5). The arithmetic mean of the value of the coefficient $\alpha_{2}$ is 11.5. The calculated $\mathrm{C}_{\mathrm{a}}$ concentration according to formula (5) with the established coefficient $\alpha_{2}$ equaling 11.5 and with appraised by van Rijn's correction coefficient equaling 2.3 was compared with the values of $\mathrm{C}_{\mathrm{a}}$ concentration taken from concentration profiles (Tab. 3).

The difference of results of reference concentration $\left(\mathrm{C}_{\mathrm{a}}\right)$ calculated according van Rijn with correction coefficient equaling 11.5 and reference concentration appraised from the concentration profiles ranges from $-8.4 \%$ to $14.7 \%$ for discharge equal $0.44 \mathrm{~m}^{3} \cdot \mathrm{s}^{-1}$, for discharge $1.96 \mathrm{~m}^{3} \cdot \mathrm{s}^{-1}$ the difference of results is from $0.4 \%$ to $15.6 \%$ and for discharge $7.41 \mathrm{~m}^{3} \cdot \mathrm{s}^{-1}$ it is within the range of $3.6 \%$ to $12.1 \%$.

\section{CONCLUSIONS}

Application of the van Rijn's method in calculations of suspended sediment transport requires proper appraisal of suspended sediment concentration on the reference level "a" above the bed. As it was demonstrated on the example of the Dłubnia river $\mathrm{C}_{\mathrm{a}}$ concentration calculated according to the empiric formula given by van Rijn where the correction coefficient is 2.3 is over five times higher than the value of real $C_{a}$ concentration calculated from concentration profiles. Disposing of measurement result the correction coefficient $\alpha_{2}$ for the A-A measurement cross-section in the Dhubnia river was determined. This coefficient equals 11.5 and with regard to the amount of data constituting the base of its determination should be adopted as an approximate value. To make the value of this coefficient more precise execution of additional series of measurements in differentiated conditions of sediment concentration water discharges is required.

The presented attempt at calculation of $\mathrm{C}_{\mathrm{a}}$ concentration according to van Rijn showed that the obtained results may depart significantly from the value of real concentration, and so the calculated amount of transported suspended sediment may be charged with a significant error. Adoption of van Rijn's method requires verification and adaptation to hydrological conditions of Polish rivers. 
TABLE 3. Suspended sediment concentration in the Dlubnia river in cross-section A-A according to measurements and van Rijn's formula

\begin{tabular}{|c|c|c|c|c|c|c|c|c|}
\hline \multirow{2}{*}{$\begin{array}{l}\text { Discharge } \\
{\left[\mathrm{m}^{3} \cdot \mathrm{s}^{-1}\right]}\end{array}$} & \multirow{2}{*}{$\begin{array}{l}\text { Concentration } \mathrm{C}_{\mathrm{a}} \\
{\left[\mathrm{g} \cdot \mathrm{m}^{-3}\right]}\end{array}$} & \multicolumn{7}{|c|}{ Measurement verticals } \\
\hline & & $\mathrm{I}$ & II & III & IV & $\mathrm{V}$ & VI & VII \\
\hline \multirow{3}{*}{0.44} & $\begin{array}{l}\text { Acc. to } \\
\text { measurements }\end{array}$ & 25.5 & 32.2 & 33.0 & 34.2 & 34.1 & 34.4 & 29.5 \\
\hline & \begin{tabular}{|l|} 
Acc. to equation \\
(4) for $\alpha_{2}=11.5$ \\
\end{tabular} & 22.5 & 32.5 & 34.3 & 29.2 & 36.9 & 33.2 & 31.7 \\
\hline & $\begin{array}{l}\text { Acc. to equation } \\
\text { (4) for } \alpha_{2}=2.3 \\
\text { acc. to van Rijn }\end{array}$ & 110.5 & 159.8 & 168.5 & 143.3 & 181.3 & 163.0 & 155.4 \\
\hline \multirow{3}{*}{1.96} & $\begin{array}{l}\text { Acc. to } \\
\text { measurements }\end{array}$ & 219.3 & 227.3 & 232.2 & 235.0 & 243.3 & 223.0 & 215.0 \\
\hline & $\begin{array}{l}\text { Acc. to equation } \\
\text { (4) for } \alpha_{2}=11.5 \\
\end{array}$ & 184.7 & 210.0 & 222.3 & 226.1 & 242.3 & 221.3 & 193.7 \\
\hline & $\begin{array}{l}\text { Acc. to equation } \\
\text { (4) for } \alpha_{2}=2.3 \\
\text { acc. to van Rijn }\end{array}$ & 832.5 & 965.1 & 1044.7 & 1064.3 & 1140.4 & 1039.1 & 841.9 \\
\hline \multirow{3}{*}{7.41} & \begin{tabular}{|l|} 
Acc. to \\
measurements \\
\end{tabular} & 229.8 & 254.3 & 302.2 & 301.0 & 278.0 & 256.0 & 225.5 \\
\hline & $\begin{array}{l}\text { Acc. to equation } \\
\text { (5) for } \alpha_{2}=11.5 \\
\end{array}$ & 248.5 & 285.0 & 323.7 & 311.8 & 296.1 & 273.8 & 242.6 \\
\hline & $\begin{array}{l}\text { Acc. to equation } \\
(5) \text { for } \alpha_{2}=2.3 \\
\text { acc. to van Rijn }\end{array}$ & 1220.2 & 1399.4 & 1589.8 & 1531.3 & 1453.9 & 1344.6 & 1191.5 \\
\hline
\end{tabular}

\section{REFERENCES}

BARTNIK W., BANASIK K., KSIAZŻEK K., RADECKI-PAWLIK A., STRUŻYŃSKI A. 2004: Hydrodynamics balance of the Skawa River within the influence of the back water of the Swinna Poreba water reservoir. 12th Inter. Conf. on „Transport and sedimentation of solid particles", Zesz. Nauk. AR we Wroctawiu, Nr 481, 135-142.

BEDNARCZYK T. 1994: Określenie ilości unoszonego rumowiska w przekroju małego zbiornika wodnego w Zesławicach. [Determination of the suspended load amount within the cross-section of a small water reservoir in Zesławice]. Zesz. Nauk. AR w Krakowie nr 229, Inżynieria Środowiska z. 15, Kraków, 7-18.

DYNOWSKA I., TLAŁKA A. 1970: Krążenie wód podziemnych na Wyżynie
Krakowskiej i Miechowskiej. [Underground water circulation on Cracow and Miechów Plateu]. Folia Geographica, Ser. Geographica-Physica, vol. IV, Kraków, 38-49.

PN-R-04032. 1998: Gleby i utwory glebowe. Pobieranie próbek i oznaczenie składu. [Soils and soil formations. Collecting of samples and determination of granulometric composition].

MOKWA M. 2002: Sterowanie procesami fluwialnymi w korytach rzek przekształconych antropogenicznie. [Fluvial processes control in anthropogenically modified river beds]. Zesz. Nauk. AR we Wrocławiu, nr 439, Rozprawy CLXXXIX, 135.

Procedura pomiarowa. Pomiar natężenia przepływu za pomoca młynka hydrometrycznego - wykonany w bród. [Measuring procedure. Measurement of 
flow intensity using hydrometric current meter - executed in ford]. IMGW/PSHM/ $\mathrm{SPO} / \mathrm{POM} / 2002$, Materiały Instytutu Meteorologii i Gospodarki Wodnej, Kraków, 2002, 16.

ROEHL J. 1962: Sediment source area, delivery rations and influencing morphological factors. IAHS publ. 59, 202-213.

WISCHMEIER H.W., SMITH D.D. 1965: Predicting rainfall erosion lossesaquide from cropland east of the Rocky Mountains. USDA, Agriculture Handbook, No 282, 47.

WIŚNIEWSKI B., KUTROWSKI M. 1973: Budownictwo specjalne w zakresie gospodarki wodnej. Zbiorniki wodne. Prognozowanie zamulania. [Water management special building structures. Water reservoirs. Silting processes forecast]. Wytyczne instruktażowe. Biuro Studiów i Projektów Budownictwa Wodnego „Hydroprojekt”, Warszawa, 55.

VAN RIJN L.C. 1984: Sediment transport. Part II: Suspended load transport. Journal of Hydraulic Engineering, vol. 110, No 10, 1613-1641.

Streszczenie. Określenie koncentracji rumowiska unoszonego na poziomie odniesienia metoda van Rijna. W pracy przedstawiono wyniki pomiarów koncentracji rumowiska $w$ rzece Dłubni przy zróżnicowanych przepływach wynoszacych 0,44 $\mathrm{m}^{-3} \cdot \mathrm{s}^{-1}$ i $1,96 \mathrm{~m}^{-3} \cdot \mathrm{s}^{-1}$ oraz $7,41 \mathrm{~m}^{-3} \cdot \mathrm{s}^{-1}$. Pomiary koncentracji rumowiska unoszonego wykonano w przekroju poprzecznym w km 10+720 rzeki Dłubni, poza zasieggiem oddziaływania cofki zbiornika w Zesławicach. Koncentrację rumowiska unoszonego określono przyrządem fotooptycznym Portable Suspended Solids and Turbidity Monitor System 770 firmy Partech. Prędkość przepływu wody mierzono za pomocą indukcyjnego młynka hydrometrycznego typu Nautilus C 2000 OTT Hydrometrie. Pomiary prędkości przepływu i koncentracji rumowiska wykonano w siedmiu pionach hydrometrycznych.

Opracowane na podstawie pomiarów hydrometrycznych profile koncentracji umożliwiły określenie koncentracji $\mathrm{C}_{\mathrm{a}}$ na poziomie odniesienia ,a" nad dnem. Otrzymane koncentracje $\mathrm{C}_{\mathrm{a}}$ po- równano $\mathrm{z}$ wartościami otrzymanymi $\mathrm{z}$ obliczeń wzorem van Rijna. Obliczając koncentrację rumowiska na poziomie odniesienia ważne jest określenie wysokości form dennych. Stwierdzono, że w rzece Dłubni przy badanych przepływach nie występowały formy denne. Zgodnie z metodyką opracowaną przez van Rijna przyjęto poziom odniesienia „a” równy 0,01 napełnienia $\mathrm{w}$ poszczególnych pionach pomiarowych. Obliczono koncentrację rumowiska na poziomie odniesienia ,a” według wzoru opracowanego przez van Rijna, w którym współczynnik korekcyjny $\alpha_{2}$ wynosi 2,3 . Stwierdzono, że obliczona wzorem van Rijna koncentracja $C_{a}$ jest ponadpięciokrotnie wyższa od określonej z profili koncentracji. Uzyskanie z obliczeń wzorem empirycznym wartości koncentracja $\mathrm{C}_{\mathrm{a}}$ zbliżonych do wartości rzeczywistych wymaga określenia współczynnika korekcyjnego $\alpha_{2}$. Dysponując pomiarami koncentracji i opracowanymi profilami koncentracji podjęto próbę wyznaczenia współczynnika korekcyjnego $\alpha_{2}$. Został on wyznaczony z przekształconego równania van Rijna, przyjmując wartości $C_{a}$ określone $w$ wyniku pomiarów. Średnia arytmetyczna wartość współczynnika $\alpha_{2}$ wynosi 11,5. Różnica wyników koncentracji $\mathrm{C}_{\mathrm{a}}$ obliczonej wzorem van Rijna ze współczynnikiem korekcyjnym $\alpha_{2}$ wynoszącym 11,5 i koncentracji $C_{a}$ określonej z profili koncentracji wynosi od $-8,4 \%$ do $14,7 \%$ dla przepływu $0,44 \mathrm{~m}^{3} \cdot \mathrm{s}^{-1}$, dla przepływu $1,96 \mathrm{~m}^{3} \cdot \mathrm{s}^{-1}$ różnica wyników wynosi od $0,4 \%$ do $15,8 \%$ a dla przepływu $7,41 \mathrm{~m}^{3} \cdot \mathrm{s}^{-1}$ mieści się w przedziale od $-3,6 \%$ do $-12,1 \%$. Wyznaczona wartość współczynnika korekcyjnego $\alpha_{2}$ wynosząca 11,5 ze względu na ilość danych, na podstawie których została ustalona, należy przyjąć jako wartość przybliżoną. Uściślenie wartości współczynnika korekcyjnego wymaga wykonania serii dodatkowych pomiarów przy zróżnicowanych warunkach przepływu wody i rumowiska.

Przeprowadzona wstępna ocena możliwości zastosowania wzoru van Rijna, służącego wyznaczeniu tej koncentracji na poziomie odniesienia „a" nad dnem wykazała, że stosowanie tej metody w określeniu koncentracji $\mathrm{C}_{\mathrm{a}} \mathrm{w}$ rzece Dłubni nie daje zadowalających rezultatów. Wyniki obliczeń wzorem podanym przez van Rijna w rzekach dorzecza górnej Wisły mogą być obarczone błędami. Wskazywać to może na również błędne obliczenie transportu rumowiska unoszonego metoda van Rijna. Adaptacja tej metody wymaga dalszej weryfikacji i adaptacji. 
Stowa kluczowe: rzeka, rumowisko unoszone, koncentracja rumowiska, profil koncentracji.

MS. received November 2008

Author's address:

Bogusław Michalec

Katedra Inżynierii Wodnej

Uniwersytet Rolniczy

Al. A. Mickiewicza 24/28

30-059 Kraków

e-mail: rmmichbo@cyf-kr.edu.pl 